\title{
EXPERIMENTAL ARTHRITIS ASSOCIATED WITH AUTO-IMMUNIZATION TO INFLAMMATORY EXUDATES
}

BY

\author{
JULIA M. PHILLIPS, P. KAKLAMANIS, AND L. E. GLYNN \\ M.R.C. Rheumatism Research Unit, Canadian Red Cross Memorial Hospital, Taplow, near Maidenhead, Berks.
}

Dumonde and Glynn (1962) reported the production of an arthritis in rabbits by an immunological reaction to fibrin. Rabbits were first immunized with either human fibrin or with their own fibrin and their knee joints were then injected with a suspension of the same fibrin as used for the immunization. When foreign fibrin was used, a high incidence of arthritis was induced which in some instances was still active 14 weeks after a single intra-articular injection. The incidence of arthritis was much lower when autochthonous fibrin was used but did nevertheless occur in a significant number of animals. It was therefore suggested that a chronic non-infective arthritis might arise naturally on the basis of an autoimmune reaction not only to fibrin but perhaps to other constituents of an inflammatory exudate. It also appeared conceivable that the alteration of the serum proteins and cell products associated with the formation of an inflammatory exudate might render them more readily autoantigenic than fibrin itself prepared from the clotting of plasma in vitro. To test this, inflammatory exudates were obtained from rabbits by a modification of the inflammatory pouch used by Selye (1953) to study inflammatory exudates in rats. The sterile exudates obtained after 7 to 14 days were incorporated with Freund's complete adjuvant and used for immunization. A number of the animals so treated gave skin reactions of delayed type when tested 10 to 14 days later by intradermal injection of the exudate alone. Autochthonous exudate was then injected into both knee joints and the joints were subsequently examined for evidence of active arthritis. The results support the hypothesis that a chronic arthritis can arise as a result of autoimmunization to some constituent or constituents of an inflammatory exudate.

\section{Material and Methods}

(1) Preparation of Pouches.-Rabbits were given four to six daily injections of 20 to $50 \mathrm{ml}$. air subcutaneously at the same site on the back or flank over a period of 7 to 14 days. When it became apparent that a discrete pocket of air had been formed, $2 \mathrm{ml}$. sterile 1 per cent. croton oil in arachis oil were injected into it. The animals were palpated daily. They were judged to be ready for operation when a firm moveable mass could be felt under the skin. This was usually found 7 to 14 days after the injection of the oils. Operations were carried out under Nembutal anaesthesia and sterile conditions. The skin at the site of operation was shaved and cleaned with Hibitane. A longitudinal incision was made over the pouch and this was dissected free and transferred to a sterile container in which it was kept at $4^{\circ} \mathrm{C}$. for not more than 24 hours. The site from which the pouch had been removed was dusted with sulphamezathine powder and the wound closed with thread sutures. The progress of the rabbits was uneventful and the wounds healed satisfactorily.

(2) Preparation of Exudates.-The pouches were carefully opened under sterile conditions and the content scraped out and transferred to sterile bottles. The exudate usually consisted of a thick creamy mass of cello filling the pouch and adhering to its walls, but sometimes there was a central accumulation of clear rather viscous fluid. On one occasion this fluid was collected separately from the cellular exudate and used for immunization, but the results of skin tests were negative. In all other cases the cellular and clear parts of the exudate were pooled.

Exudates were stored at $-20^{\circ} \mathrm{C}$. until required. After thawing they were homogenized by means of an M.S.E. homogenizer and strands of connective tissue which had been scraped from the inside of the pouch were removed. The homogenates were then mixed with sufficient sterile isotonic saline to allow them to flow easily, and sonicated by an M.S.E. Ultrasonic Disintegrator No. 3000. The sonicates were stored at $-20^{\circ} \mathrm{C}$. while nitrogen determinations on samples of them were carried out according to the method of Fawcett (1954). Nitrogen values were multiplied by 6.25 to arrive at estimates of the protein concentrations.

(3) Immunization.-Animals were immunized by multiple intradermal injections in the neck region on two occasions. For auto-exudate immunization, the antigen dose was $18 \mathrm{mg}$. exudate protein in $1 \mathrm{ml}$. of a Freund's complete adjuvant emulsion, except in three animals which produced insufficient exudate and these received smaller doses as descriied under "Results". The time between the two immunizations was 3 to 4 weeks. For homo-immunization the dose was $10 \mathrm{mg}$. exudate in Freund's complete adjuvant and the interval between immunizations was 7 weeks. 
The animals were skin-tested 14 to 16 days after the first immunization and 6 to 14 days after the second, 24 hours.

(4) Sterility Tests.-Samples of all exudates were taken before and after homogenization and sonication, and also immediately before injection, and these were cultured aerobically on blood agar plates and anaerobically in Robertson's cooked meat broth. Any which were found to be contaminated were discarded. Swabs were taken from knee joints at autopsy and cultured in a similar fashion.

(5) Joint Injections.-10 mg. auto- or homo-exudate protein in $1 \mathrm{ml}$. sterile isotonic saline were injected into both knee joints of each rabbit under Nembutal anaesthesia. The knees before injection were carefully shaved and cleaned with Hibitane. As a control the knee joints of five normal rabbits were injected with $1 \mathrm{ml}$. of a $1: 40$ mixture of 1 per cent. croton oil in arachis oil in saline, since this was calculated to be the maximal amount of oil which could have remained in the exudates and been injected into the knee joints at the concentration used.

A total of forty animals was used, divided into the following groups:

I. Autoimmunized.-Eleven rabbits (Nos. 2, 7, 9, 10, $12,14,15,16,17,18$, and 19) were immunized with their own exudate and injected intra-articularly with their own exudate.

II. NON-IMMUNIZED HomoLogous.-Fourteen rabbits (Nos. 21-28 and 35-40) were not immunized but were injected intra-articularly with exudate obtained from other rabbits.

III. IMMUNIZED Homologous.-Fourteen rabbits with $100 \mu \mathrm{g}, 10 \mu \mathrm{g}$., and $1 \mu \mathrm{g}$. of exudate protein in $0 \cdot 1$ $\mathrm{ml}$. sterile isotonic saline. They were examined at 4 and

(Nos. 29-34 and 159/1-8) were immunized with exudate from other rabbits and subsequently injected intra- $\vec{\nabla}$ articularly with the corresponding exudate.

IV. NON-IMMUNIZED Autologous.-Three rabbits (Nos. 47, 49 and 51) were not immunized but injected $\frac{\square}{\omega}$ intra-articularly with their own inflammatory exudate.

V. OIL Controls.-Five rabbits (Nos. 53-57) injected $\overrightarrow{\vec{*}}$ intra-articularly with a suspension of the croton oil solution diluted $1: 40$ in saline.

(6) Killing of Animals.-At various intervals after knee- $\frac{\bar{\sigma}}{\bar{n}}$ joint injection, the animals were killed by Nembutal $\frac{\bar{\rho}}{}$ overdose. Many of them were bled by cardiac puncture at that time. The knees were shaved and cleaned withn Cetavlon. The skin was removed and a cut made across"s the quadriceps tendon and down on either side of the $\overrightarrow{0}$ patella with a sterile scalpel blade until a swab could be $\overrightarrow{-}$ inserted into the joint space. After this had been taken for sterility tests, the joint space was opened further and $\frac{\mathrm{O}}{\mathrm{O}}$ the whole joint was stripped of muscle and fixed for sectioning.

(7) Histology.-The knee joints were fixed and decalci-iv fied as described by Dumonde and Glynn (1962). After $\overrightarrow{-}$ decalcification, the joints and patellae were sectioned ando embedded according to the second method of Russello (1956).

(8) Complement-Fixation Tests.-Sera from several 3 animals were tested for antibody by complement fixation, using 2.5 M.H.D. of fresh guinea-pig serum as a source? of complement and $100 \mu \mathrm{g} ., 10 \mu \mathrm{g}$., and $1 \mu \mathrm{g}$. quantities (with respect to protein) of the appropriate immunizing exudate. (All such tests were negative.)

\section{Results}

(1) Skin Tests.-These are summarized in Table $\mathrm{I} . \bar{\partial}$

ARTHRITIS AND 24-HOUR SKIN TESTS OF IMMUNIZED ANIMALS

\begin{tabular}{|c|c|c|c|c|c|c|c|}
\hline \multirow{2}{*}{$\begin{array}{l}\text { Rabbit } \\
\text { Nos. }\end{array}$} & \multirow{2}{*}{$\begin{array}{l}\text { Days after } \\
\text { Immunization }\end{array}$} & \multirow{2}{*}{$\begin{array}{c}\text { Reaction (mm.) to } \\
\text { Test Dose of } \\
100 \mu \mathrm{g} .\end{array}$} & \multirow{2}{*}{$\begin{array}{c}\text { Days after } \\
\text { Re-immunization }\end{array}$} & \multirow{2}{*}{$\begin{array}{l}\text { Reaction to } \\
\text { Test Dose of } \\
100 \mu \mathrm{g}\end{array}$} & \multicolumn{2}{|c|}{ Arthritis in Knee } & \multirow{2}{*}{ Immunization } \\
\hline & & & & & Right & Left & \\
\hline $\begin{array}{l}2 \\
7 \\
9 \\
10 \\
12 \\
14 \\
15 \\
16^{*} \\
16+ \\
17 \\
18 \\
19\end{array}$ & $\begin{array}{l}14 \\
14 \\
14 \\
15 \\
16 \\
14 \\
15 \\
14 \\
14 \\
14 \\
14 \\
14\end{array}$ & $\begin{array}{r}8 \\
12 \\
10 \\
10 \\
<4 \\
<4 \\
7 \\
<4 \\
9 \\
9 \\
7 \\
9\end{array}$ & $\begin{array}{r}10 \\
10 \\
10 \\
6 \\
6 \\
10 \\
6 \\
6 \\
9 \\
10 \\
10 \\
9\end{array}$ & $\begin{array}{r}6 \\
8 \\
8 \\
9 \\
<4 \\
<4 \\
8 \\
<4 \\
6 \\
7 \\
6 \\
10\end{array}$ & $\begin{array}{r}0 \\
+ \\
0 \\
++ \\
0 \\
0 \\
++ \\
\mathbf{N T} \\
+++ \\
++ \\
++ \\
+++\end{array}$ & $\begin{array}{r}0 \\
0 \\
0 \\
++ \\
0 \\
0 \\
+ \\
\text { NT } \\
++ \\
++ \\
++ \\
+++\end{array}$ & $\begin{array}{l}\text { With } \\
\text { Autochthonous } \\
\text { Exudate }\end{array}$ \\
\hline $\begin{array}{c}29 \\
30 \\
31 \\
32 \\
33 \\
34 \\
159 / 2 \\
159 / 3 \\
159 / 4 \\
159 / 5 \\
159 / 6 \\
159 / 8 \\
159 / 9 \\
159 / 10\end{array}$ & $\begin{array}{l}14 \\
14 \\
14 \\
14 \\
14 \\
14 \\
= \\
= \\
= \\
= \\
=\end{array}$ & $\begin{array}{r}<4 \\
<4 \\
9 \\
6 \\
8 \\
6 \\
\text { NT } \\
\text { NT } \\
\text { NT } \\
\text { NT } \\
\text { NT } \\
\text { NT } \\
\text { NT } \\
\text { NT }\end{array}$ & $\begin{array}{r}13 \\
13 \\
13 \\
13 \\
13 \\
13 \\
7 \\
7 \\
7 \\
7 \\
7 \\
7 \\
7\end{array}$ & $\begin{array}{r}<4 \\
8 \\
10 \\
12 \\
16 \\
7 \\
13 \\
16 \\
14 \\
10 \\
8 \\
6 \\
4 \\
6\end{array}$ & $\begin{array}{r}++ \\
+ \\
++ \\
0 \\
++ \\
0 \\
++ \\
++ \\
++ \\
+ \\
0 \\
0 \\
++ \\
++ \\
++\end{array}$ & $\begin{array}{r}+++ \\
0 \\
0 \\
+ \\
++ \\
0 \\
++ \\
++ \\
++ \\
+ \\
+ \\
0 \\
+ \\
++\end{array}$ & $\begin{array}{l}\text { With } \\
\text { Homologous } \\
\text { Exudate }\end{array}$ \\
\hline
\end{tabular}

* Rabbit immunized and tested with clear fraction of exudate. + Rabbit immunized and tested with thick fraction of exudate. 
(2) Arthritis.-The severity of the arthritis was graded from + to +++ . The lowest grade + consisted of some villous hyperplasia, an increase of cellularity confined to the fixed cell types, and no more than an occasional plasma cell. The intermediate grade $(++)$ was characterized by the presence in addition of a conspicuous infiltration of lymphocytes and plasma cells. The highest grade $(+++)$ showed the presence of pannus, or erosions, or dense infiltrations of plasma cells, or distinct follicular aggregations of lymphocytes. In summarizing the results of the different experimental groups only Grades ++ and +++ are regarded as positive, that is as evidence of an active arthritis. Figs 1 to 8 (see pp. 168 to 171) are typical examples of the three grades. Further examples of the lesion are illustrated in Figs 9 to 12 (see pp. 172 and 173).

The incidence of arthritis of Grade ++ and over is summarized in Table II.

Since the animals were killed at different intervals after the injection of their joints, the time of killing in relation to the presence or absence of arthritis is shown in Table III. There is no evidence in this Table that the incidence of the lesions was adversely affected by delay in times of killing. In Group II, for example, lesions were confined to those killed after 4 weeks, whereas in Group I they were distinctly commoner during the earlier period. The individual figures in any group are, however, too small for analysis.

TABLE III

RELATIONSHIP OF ARTHRITIS TO TIME OF KILLING AFTER INTRA-ARTICULAR INJECTIONS OF EXUDATE

\begin{tabular}{c|l|c}
\hline \multirow{2}{*}{ Group } & \multicolumn{2}{|c}{ Time between Injection and Death (weeks) } \\
\cline { 2 - 3 } & Animals with Arthritis & Animals without Arthritis \\
\hline I & $2,2,2,5,6,9$ & $4,6,8,10,10$ \\
II & $4,8,8,10,5,7,13$ \\
III & $1,2,2,5,5,15,16,20$ & $1,2,2,2,4,5,6,7,13$ \\
IV & 3 & $5,8,12,13,24,39$ \\
V & & $8,4,5,6,11$ \\
& & $2,4,5$ \\
\hline
\end{tabular}

\section{Discussion}

It is apparent from these results that the introduc- $\frac{\bar{\zeta}}{3}$ tion into a rabbit's knee joints of a sterile inflammatory exudate from itself or from another rabbit can induce an inflammatory reaction in the synovial $\overrightarrow{\vec{D}}$ tissues. To some extent this occurs in both immunized and non-immunized recipients but is distinctly commoner in the former. Thus in Groups I and III $\frac{}{5}$ (i.e. the immunized groups) the combined incidence $\vec{\mathbb{}}$ of arthritis was fourteen out of 25 animals, whereas in Groups II and IV (the non-immunized groups) is the corresponding figures were five out of fifteen. $\overrightarrow{0}$ The incidence of involvement of individual joints was 23 out of fifty for Groups I and III and only five out $\vec{\omega}$ of thirty for Groups II and IV. These figures are statistically significant at the 0.01 level $\left(\chi^{2}=6.78 \stackrel{0}{0}\right.$ for 1 degree of freedom). When the results take on into account the severity of the lesions, as in Table IV, iv the effect of immunization is even more apparent, $\vec{\sigma}$ the score for the two immunized groups being more $v$ than three times that for non-immunized groups. $\frac{}{5}$ This difference is statistically significant at the 0.001 level.

TABLE IV

SEVERITY OF ARTHRITIS IN DIFFERENT GROUPS EXPRESSED AS A SCORE

\begin{tabular}{c|c|c|c}
\hline $\begin{array}{c}\text { Group } \\
\text { No. }\end{array}$ & Score & $\begin{array}{c}\text { Maximum } \\
\text { Possible }\end{array}$ & $\begin{array}{c}\text { Score as } \\
\text { Percentage of } \\
\text { Maximum Possible }\end{array}$ \\
\hline II & 25 & 66 & 38 \\
II & 8 & 78 & 10 \\
III & 33 & 84 & 39 \\
IV & 2 & 12 & 17 \\
V & 0 & 30 & 0 \\
\hline
\end{tabular}

* 2 points for $a++$ lesion, 3 points for $a+++$ lesion, nil for a lesion of + .

It could be argued that the presence of arthritis in some of the non-immunized animals throws doubt on the role of the immune state in the genesis of the $\overline{0}$ lesions. In both Groups II and IV, however, the possibility of immunization cannot be excluded. In Group II, in which homologous exudate was used, the presence of allotypic proteins in the exudate

TABLE II

INCIDENCE OF ARTHRITIS IN IMMUNIZED AND NON-IMMUNIZED RABBITS INJECTED INTRA-ARTICULARLY WITH INFLAMMATORY EXUDATE

\begin{tabular}{|c|c|c|c|c|c|}
\hline & Group & $\begin{array}{c}\text { No. of } \\
\text { Animals }\end{array}$ & $\begin{array}{l}\text { No. with } \\
\text { Arthritis }\end{array}$ & $\begin{array}{c}\text { No. of } \\
\text { Affected Joints }\end{array}$ & $\begin{array}{l}\text { Percentage of } \\
\text { Joints Affected }\end{array}$ \\
\hline $\begin{array}{l}\text { I } \\
\text { II } \\
\text { III } \\
\text { IV } \\
\text { V }\end{array}$ & $\begin{array}{l}\text { Autochthonus Immunized } \\
\text { Homologous Non-immunized } \\
\text { Homologous Immunized } \\
\text { Autochthonous Non-immunized } \\
\text { Oil only }\end{array}$ & $\begin{array}{r}11 \\
13 \\
14 \\
2 \\
5\end{array}$ & $\begin{array}{l}6 \\
4 \\
8 \\
1 \\
0\end{array}$ & $\begin{array}{r}9 \\
4 \\
14 \\
1 \\
0\end{array}$ & $\begin{array}{r}41 \\
15 \\
50 \\
25 \\
0\end{array}$ \\
\hline
\end{tabular}




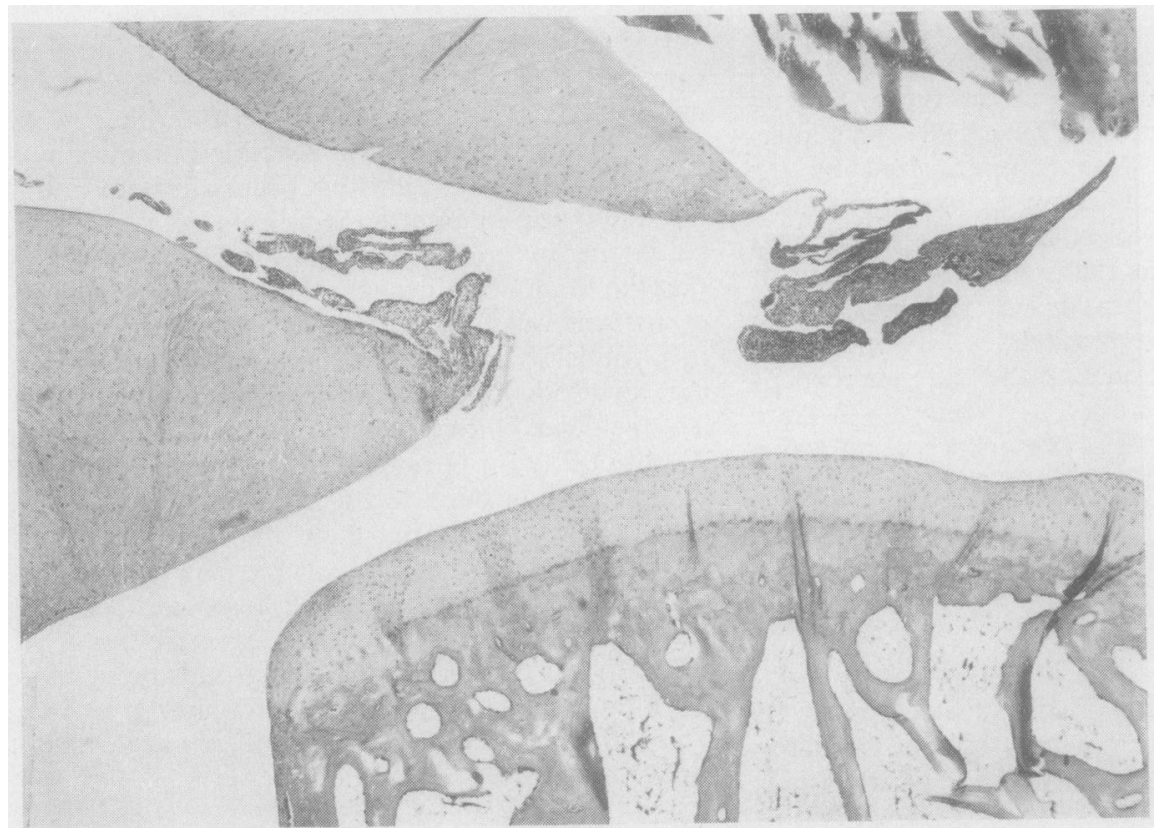

Fig. $1(161 / 73360 / 64)$. - Knee joint of an immunize rabbit 8 weeks after intra-articular injection of inflas matory exudate, showing villous hyperplasia of the synov? membrane in the intercondylar fossa and on the edge of the meniscus Grade I reaction. Haematoxylin and eosin. $\times 27$.

Fig. 2.-One of the hyperplastic villi of Fig. 1 at higherN Fig. 2.- - One of the hyperplastic villi of the cells present magnification, showing the character of the cells present

Haematoxylin and eosin. $\times 300$. 


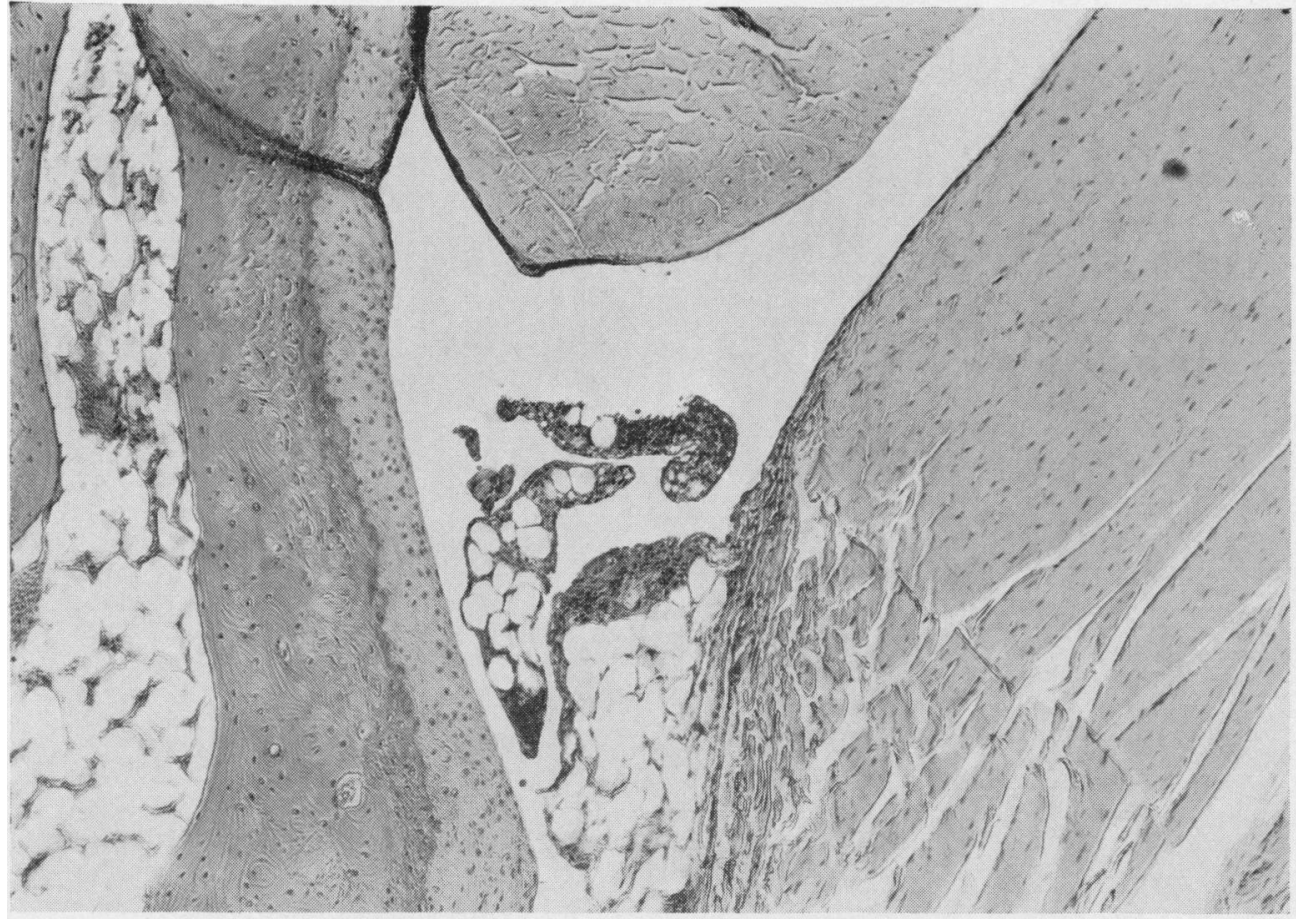

Fig. 3 (161/33. 164/65).-Knee joint of an immunized rabbit 22 weeks after intra-articular injection of inflammatory exudate showing hyperplastic villi on the cruciate ligament crowded with inflammatory cells. Grade II reaction. Haematoxylin and eosin. $\times 62 \cdot 5$.

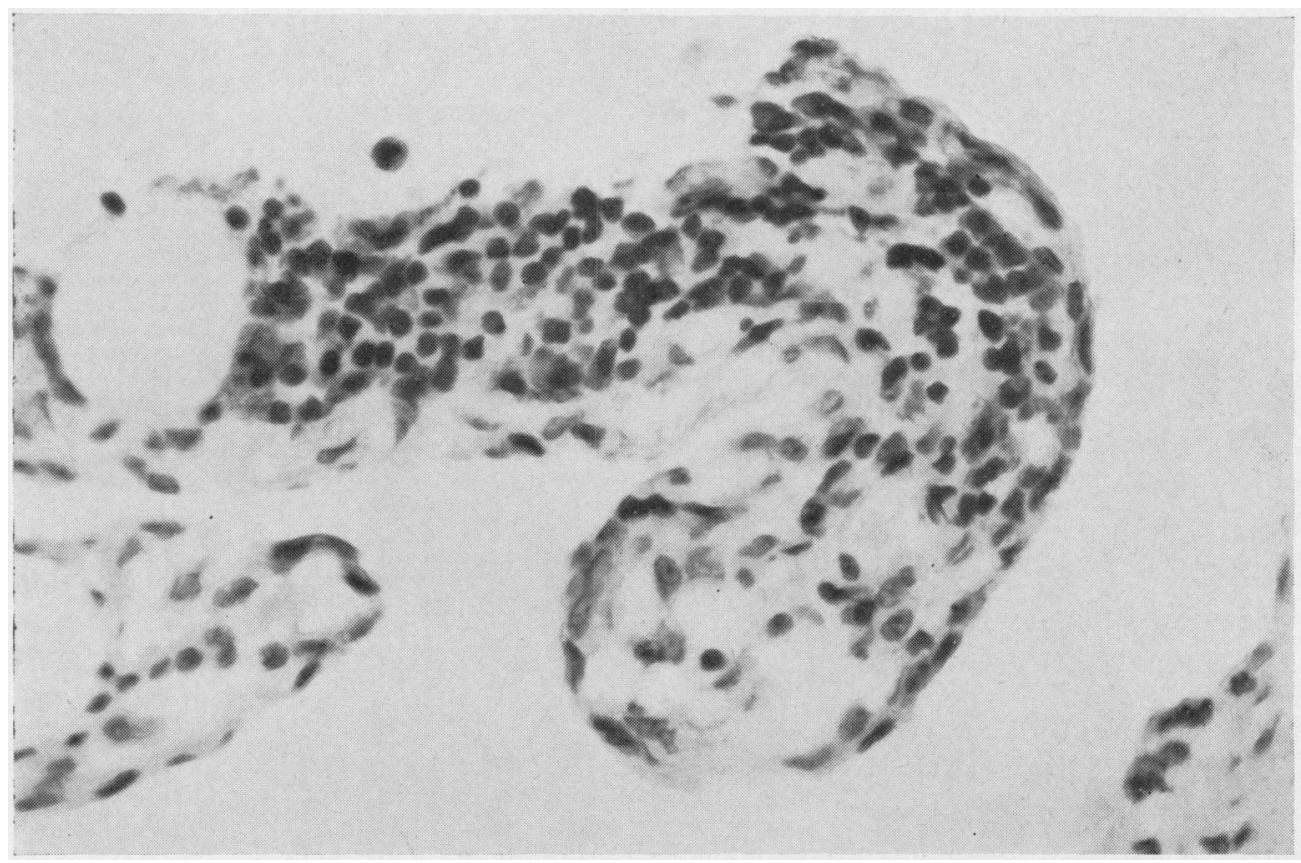

Fig. 4.-One of the villi of Fig. 3 enlarged to show the lymphocyte and plasma cell infiltrate. Haematoxylin and eosin. $\quad \times 416$. 

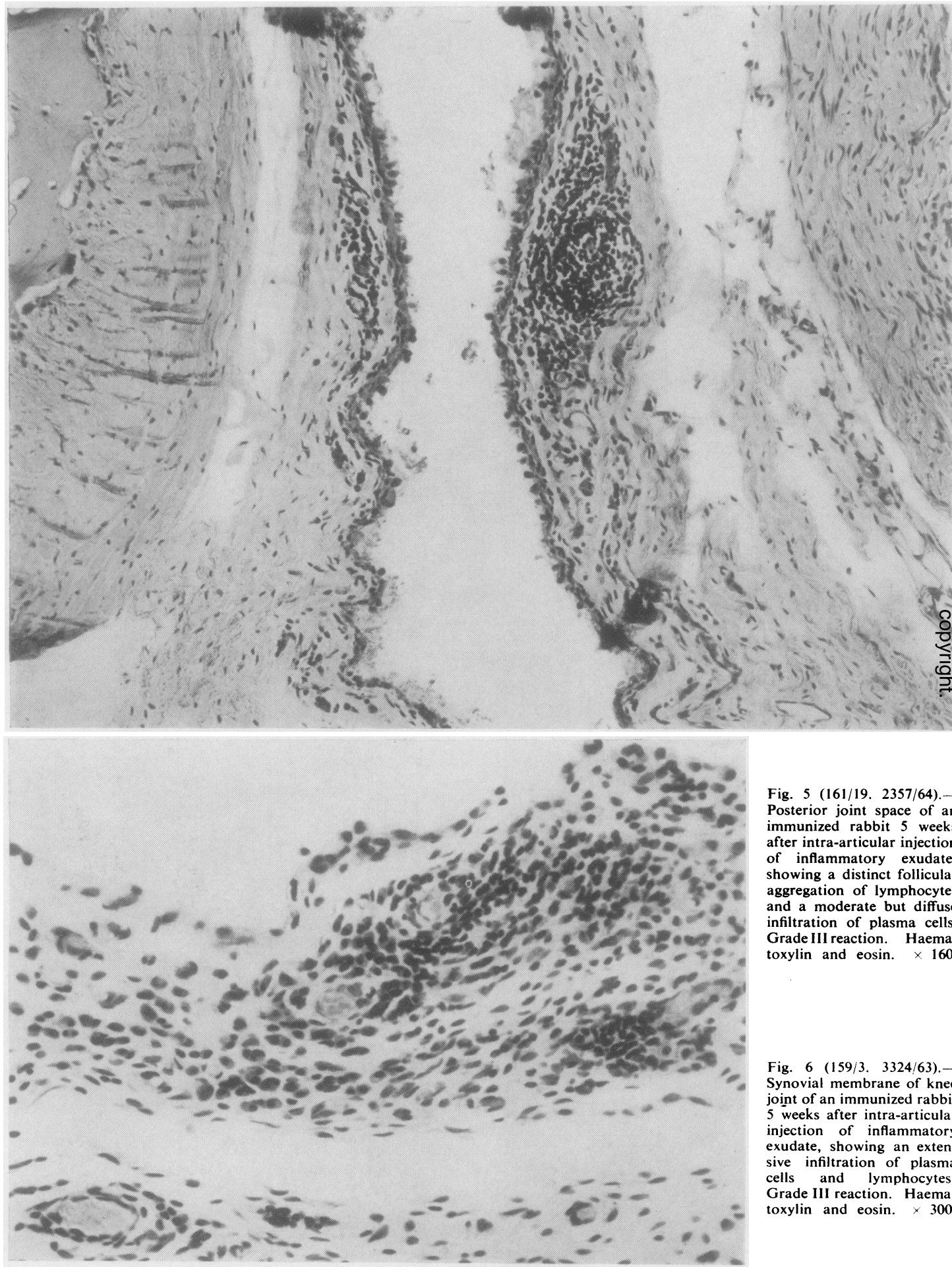

Fig. $5(161 / 19.2357 / 64)$. 응

Posterior joint space of an immunized rabbit 5 weeks after intra-articular injection of inflammatory exudate. showing a distinct follicular aggregation of lymphocytes and a moderate but diffuse $\sigma$ infiltration of plasma cells 3 . Grade III reaction. Haematoxylin and eosin. $\times 160$. O

Fig. $6(159 / 3.3324 / 63) .-N$ Synovial membrane of knee? joint of an immunized rabbit $N$ 5 weeks after intra-articular injection of inflammatory exudate, showing an exten- $\sigma$ sive infiltration of plasmare cells and lymphocytes. 0 Grade III reaction. Haematoxylin and eosin. $\times 300$. 


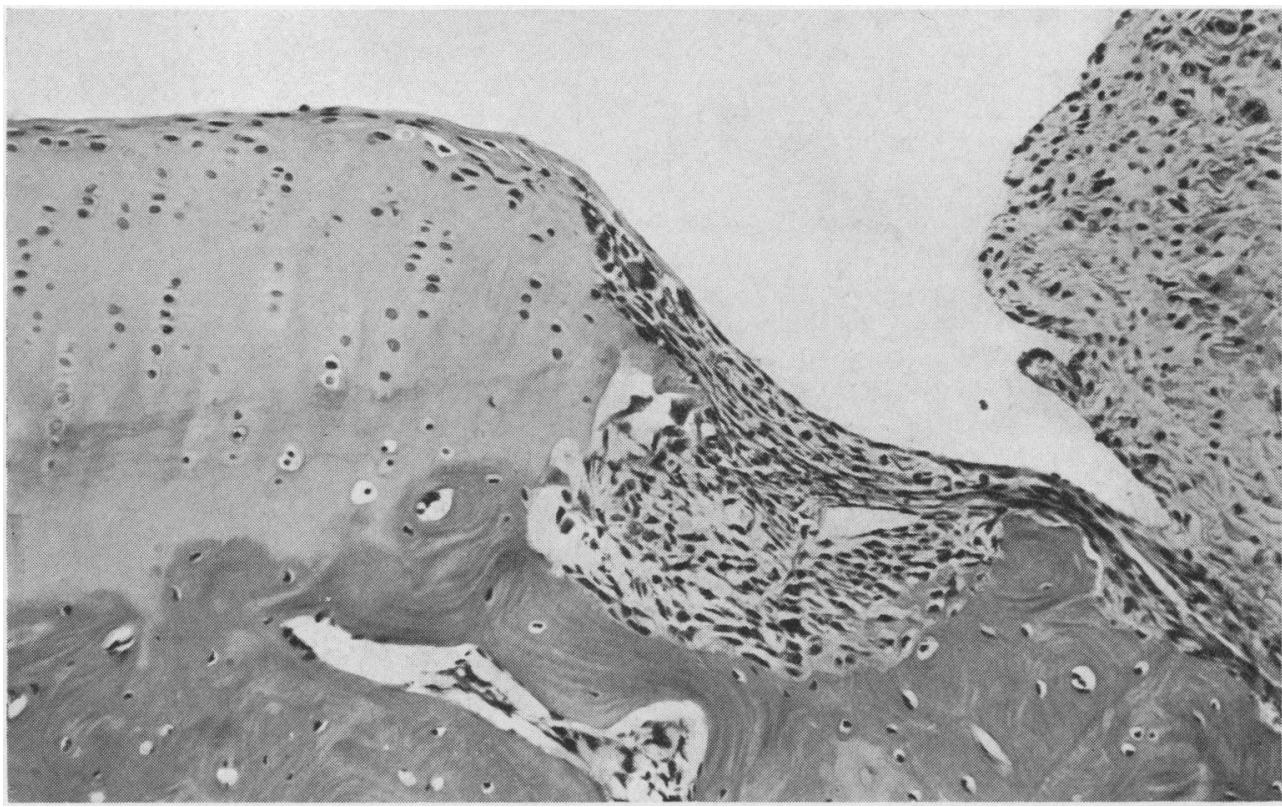

Fig. 7 (161/10. 4780/63).- Intercondylar fossa at lower end of femur from knee joint of immunized rabbit 2 weeks after intraarticular injection of inflammatory exudate, showing a well-developed erosion of the bone at the edge of the articular cartilage and early pannus formation. Grade III reaction. Haematoxylin and eosin. $\times 150$.

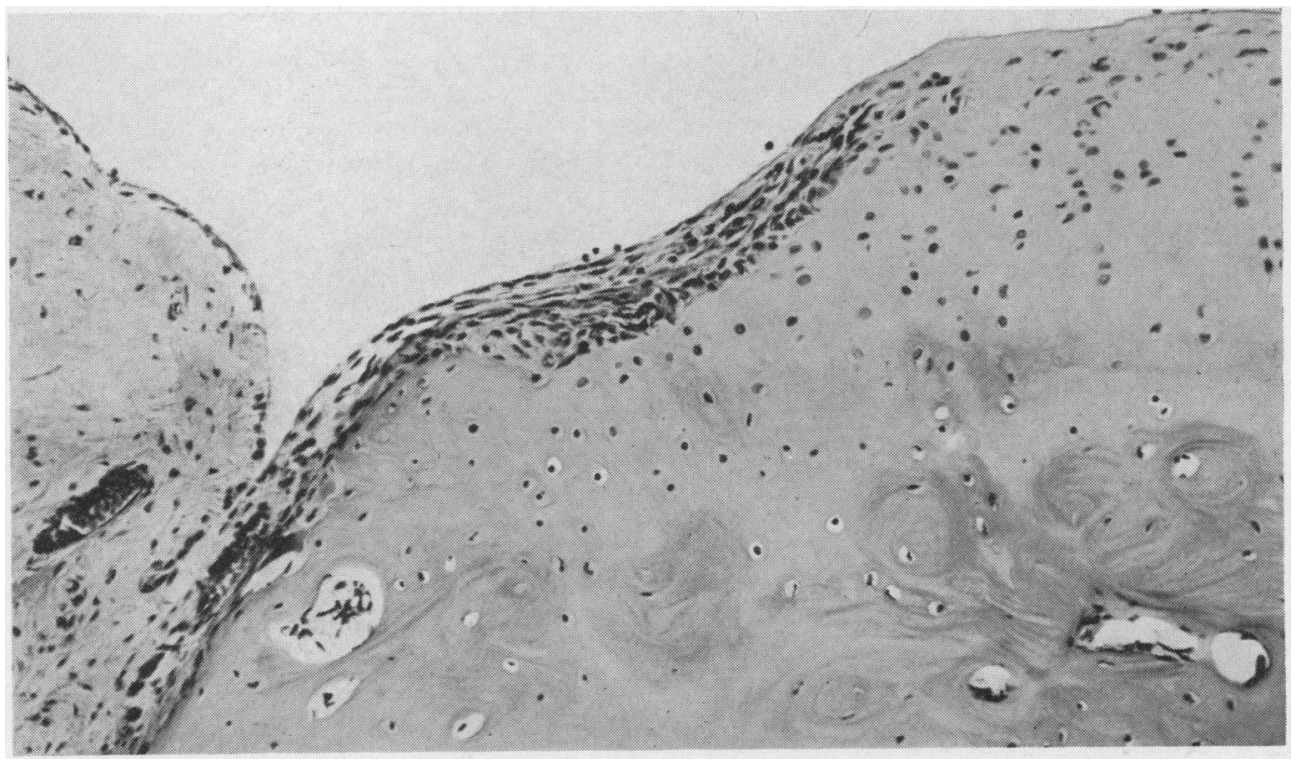

Fig. 8.-Same animal as Fig. 7, but opposite knee. A well-developed pannus extends from the intercondylar fossa across the articular surface of the femoral condyle. Haematoxylin and eosin. $\quad \times 150$. 


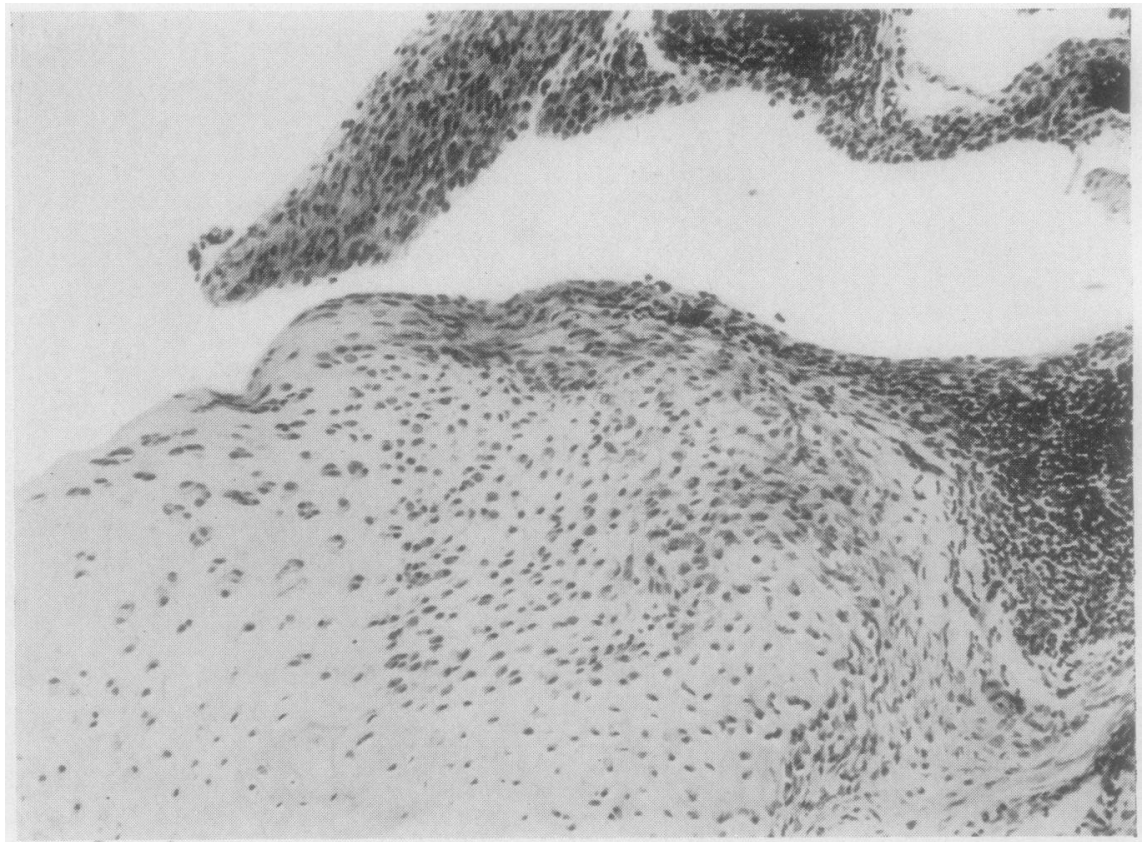

Fig. $9(159 / 10.4618 / 63)$. - Left patella of an immunized rabbit 2 weeks after intra-articular injection of homologous inflammatory exudate, showing considerable villous hyperplasia, intense cellular infiltration, early erosion, and beginning of pannus formation. Haematoxylin and eosin. $\times 116$.

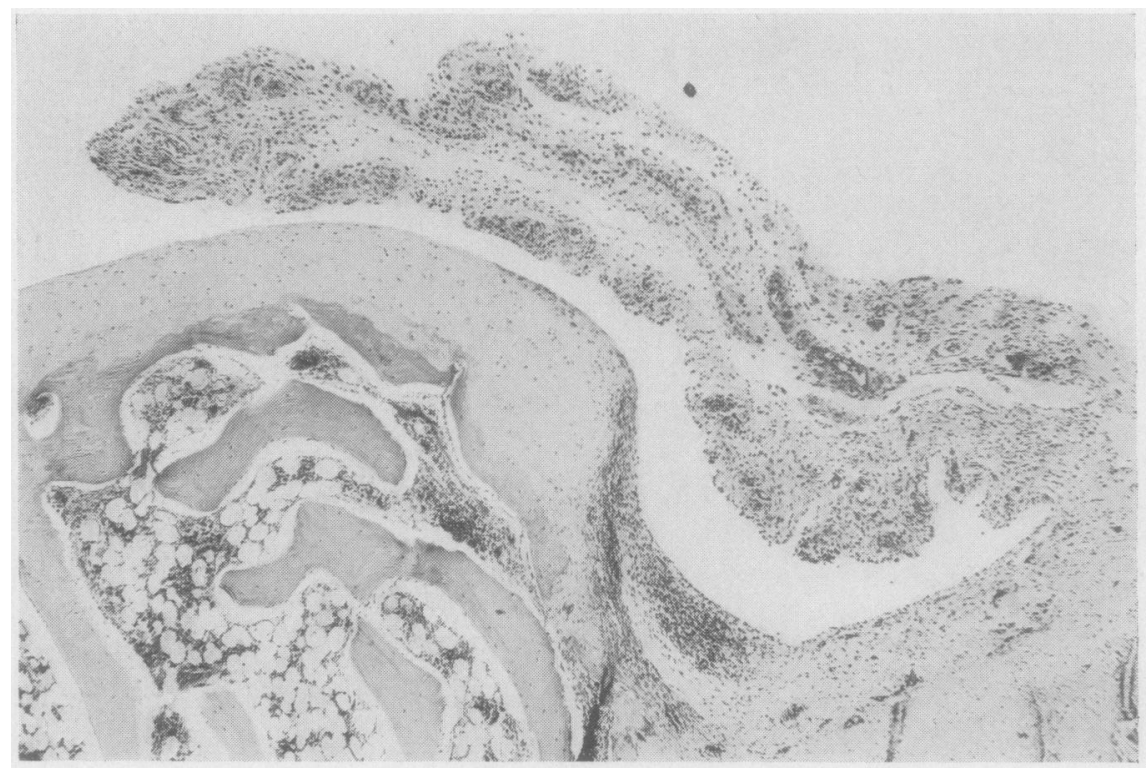

Fig. 10.-Coronal section of right knee from same animal as Fig. 9, showing villous hyperplasia of the synovial membrane on the lower end of the femur and early pannus formation. Haematoxylin and eosin. $\times 40$. 


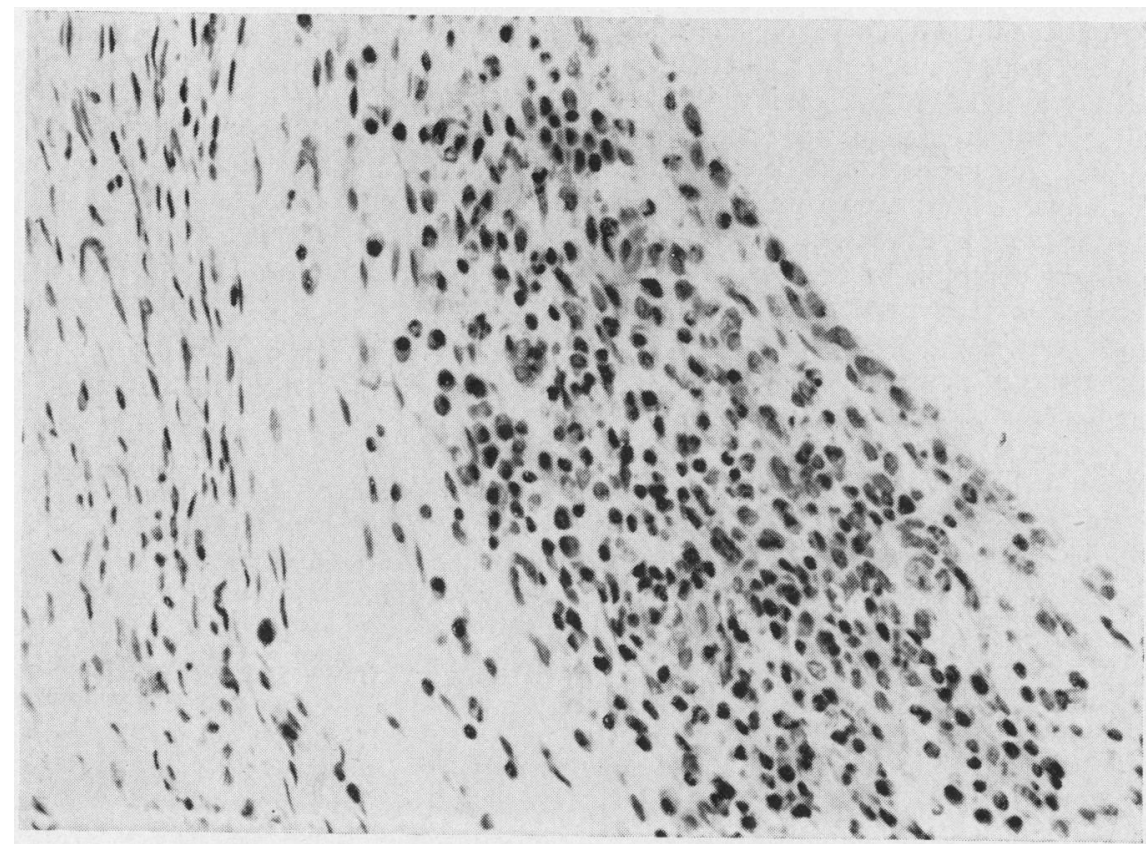

Fig. 11 (159/10. 4022/63).- Synovial membrane from right knee of same animal as Fig. 9, showing intense infiltration of lymphocytes and plasma cells. Haematoxylin and eosin. $\times 300$.

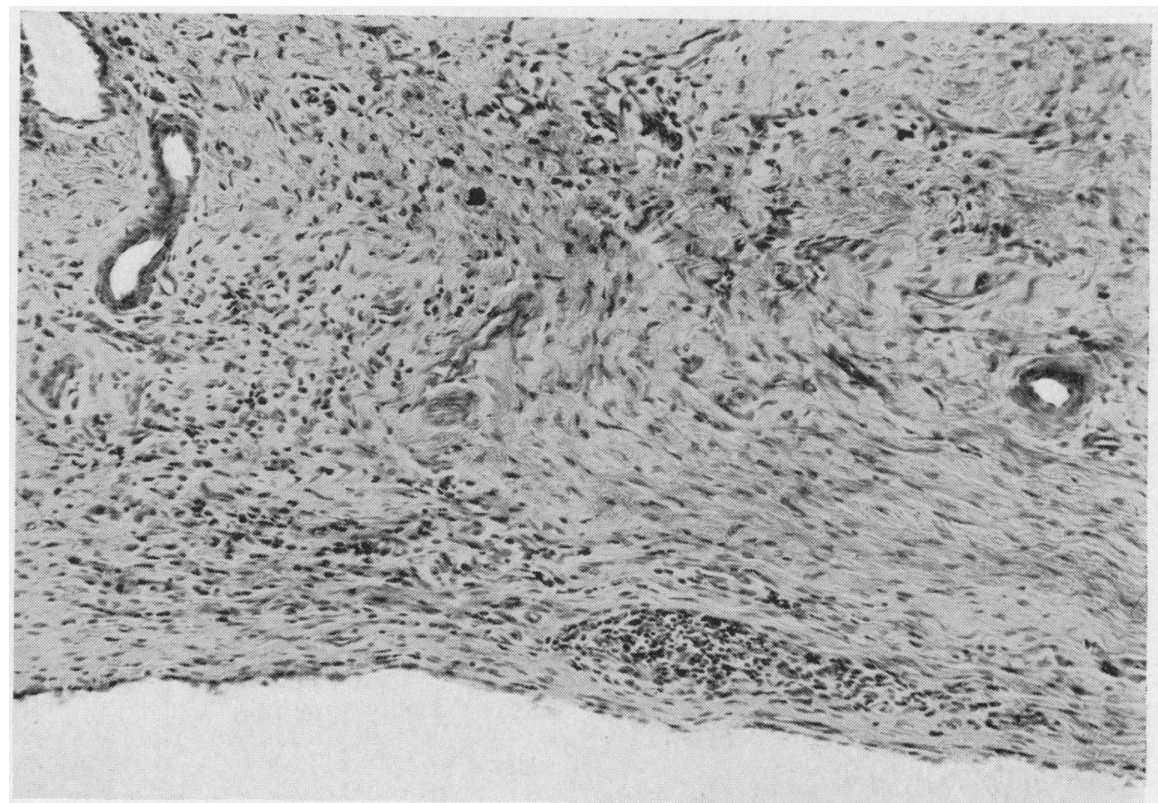

Fig. 12 (161/19. 2356/64).-Collateral ligament of left knee of same animal as Fig. 5, showing thickening and cellular infiltration which is both diffuse and follicular. Haematoxylin and eosin. $\times 120$. 
could provide an adequate antigenic stimulus (Oudin, 1960), and even in Group IV the alteration of the proteins consequent upon the inflammatory injury might lead to a similar result. It is of interest that in Group II, in which immunization could only have occurred after the exudate had been injected into the knee joints, lesions were found only in animals killed 4 or more weeks later. In Groups I and III lesions were common by the second week. Even if the lesions in Groups II and IV are not immunological in origin, the greater incidence and severity of the arthritis in the immunized groups indicates an enhancing role for immunity in their pathogenesis.

The correlation between the skin tests and the incidence of arthritis also emphasizes the importance of the immunological state in the development of the joint lesions. Thus, of the nine animals with a strong skin reaction (taken arbitrarily as one of 9 $\mathrm{mm}$. diameter or greater) seven showed arthritis of Grade ++ or higher ( 78 per cent.), whereas the incidence of similar lesions in the sixteen animals with weaker skin reactions was only 44 per cent. These results however fall short of the usually accepted level of significance $\left(\chi^{2}=2 \cdot 8\right.$ for 1 degree of freedom).

Further support for the participation of immunological reactivity in the genesis of these experimental lesions is found in their histology. The conspicuous part played by plasma cells and the tendency towards follicle formation by the aggregations of lymphocytes are characteristic of the reaction of tissues to local antigens. They are not a feature of the reaction to simple chemical irritants or to any of the pharmacologically active agents known to occur in inflammatory exudates.

If these observations are of general significance, i.e. for species other than the rabbit, it would appear that accentuation and perpetuation of inflammatory lesions of diverse aetiology could arise on the basis of an autoimmune reaction to one or more components of the exudate itself. The chronicity of such lesions would therefore be largely independent of the initiating agents. Whether chronicity in the rheumatic group of diseases is ever dependent upon such a mechanism is a tantalizing question.

\section{Summary}

(1) An inflammatory exudate was induced in rabbits by subcutaneous injection of a 1 per cent. $v / v$ solution of croton oil in arachis oil.

(2) This exudate injected into the knee joints of the same or other rabbits resulted in the development of an acute arthritis in some of the animals.
(3) In animals previously immunized with the inflammatory exudate, the incidence and the severity of the lesions were significantly greater than in those not immunized.

(4) The arthritis in some animals was still active 22 weeks after the intra-articular injection.

(5) These results support the possibility that a chronic self-perpetuating lesion may arise on the basis of autoimmunity to inflammatory exudate, irrespective of the initial cause of the inflammation.

\section{REFERENCES}

Dumonde, D. C., and Glynn, L. E. (1962). Brit. J. exp. Path., 43, 373.

Fawcett, J. K. (1954). J. med. Lab. Tech., 12, 1.

Oudin, J. (1960). C.R. Acad. Sci. Paris, 250, 770.

Russell, N. L. (1956). J. med. Lab. Tech., 13, 484.

Selye, H. (1953). Proc. Soc. exp. Biol. (N.Y.), 82, 328.

Arthrite expérimentale associée à l'auto-immunisation aux exsudats inflammatoires

\section{RÉSUMÉ}

(1) On a provoqué un exsudat inflammatoire chez le lapin par l'injection sous-cutanée d'une solution d'huile de croton à 1 pour cent dans l'huile d'arachis.

(2) Cet exsudat injecté dans l'articulation du genou du même ou d'un autre lapin provoquait une arthrite aigư⿱宀 ? chez certains de ces animaux.

(3) Chez des animaux immunisés préalablement pæi l'exsudat inflammatoire, la fréquence et la sévérité des lésions était appréciablement plus grande que chez ceux qui n'avaient pas été immunisés.

(4) Chez plusieurs animaux l'arthrite était encore $\frac{D}{\infty}$ active 22 semaines après l'injection intra-articulaire.

(5) Ces résultats viennent à l'appui de l'hypothése $\overrightarrow{\vec{O}}$ qu'une lésion chronique qui se perpetue peut dériver de l'auto-immunité à l'exsudat inflammatoire, indépendamment de la cause initiale de l'inflammation.

Artritis experimental asociada con auto-inmunización al exudato inflamatorio

\section{SUMARIO}

(1) Se produjo un exudato inflamatorio en el conejo por la inyección subcutánea de una solución de aceite de crotón a 1 por ciento en aceite de arachis.

(2) Este exudato inyectado en la articulación de la rodilla del mismo o de un otro conejo produjo una artritis aguda en algunos animales.

(3) En animales previamente inmunizados por el exudato inflamatorio, la frecuencia y la severidad de las $\mathcal{N}$ lesiones fué significativamente mayor que en los que no $N$ habían sido inmunizados.

(4) En algunos animales la artritis aún permaneció activa a los 22 semanas de la inyección intra-articular.

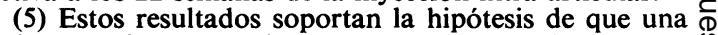
lesión crónica se puede perpetuar a causa de la auto- $\stackrel{\mathcal{C}}{\stackrel{\rho}{\rightarrow}}$ inmunidad al exudato inflamatorio, independientemente de la causa inicial de la inflamación.

标

要
.

$$
\text { 畚 }
$$

,

